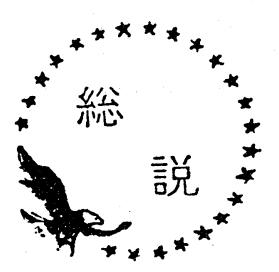

\author{
自らのエネルギーは自らの手で \\ —施策に真の裹付をエネルギーにイニシャチーブを— \\ 一一昭和 46 年 6 月 24 日受理一
}

海外原料炭開発株式会社 下 沢 舜 伍

\section{1. 原点にかえって}

通産白書にも「70年代は資源の新開拓期である」と し，布望と不安のうちにこの年代に入った。そして内 外の情勢は急速度で緊張してきて抢り, わが国のエネ ルギー確保のため, いまや思いきった施策と決断を迫 られる新開拓期を迎えることとなった。

1 ドル石油（積地実勢価格）の出現が予言された。 「エネルギー過剩と低価格時代」は逆に 2 ドル以上の 高い石油で返されつつある。原料炭の高騰, 原子力開 発の遅れ, 公害に端を発した低イオウ油の堅調, そし てOPECの攻勢と, エネルギー需給の不安定と価格 上昇への動きはむしろ構造的要因に基底する変化の兆
さえ見せはじめた。

現状のわが国の産業構造はこの安定低廉を前提とし たものだけに, その根底を摇さぶる問題であり, 脱工 業化に移行する過程で, エネルギーの流れに大きな波 瀾が予想される。

長期予想のむずかしさもあるが，エネルギー需給は ともすれば近視眼的になりがちである。フローニンゲ ンのガス噴出は欧州に新エネルギー時代の出現を告 げ, 北海の天然ガスの発見は石炭の終えんがきたかの ように喧伝され, 原子力の進出はアメリカの石炭火力 発電の急減を予見し，反面今回の O P E C の反攻に会 ってはたちまち周章狼狽するなどそのよい例である。

$$
\text { エネルギー別 }
$$$$
\begin{array}{llll}
\text { 石 } & & \text { 油 } \\
\text { 石 } & & \text { 炭 } \\
\text { 天 } & \text { 然 } & \text { ガ } & \text { ス } \\
\text { 原 } & \text { 子 } & \text { 力 } \\
\text { 水 } & \text { 力 } & \text { 他 } \\
\text { 合 } & & \text { 計 }
\end{array}
$$

注 1）Oil \& Gas J. 1969年11月10日号

注 3) 原油 $\mathrm{t} /$ 年 $\rightarrow$ 石炭 $\mathrm{t} /$ 年 換算 1.4 倍
表 1 世界エネルギー別 原油換算 100 万 bbl/日

\begin{tabular}{cccc}
\hline 1968年 & 1970 年 & 1975年 & \multicolumn{1}{c}{1980 年 } \\
$39.54(43.9 \%)$ & $45.26(45.6 \%)$ & $62.07(49.6 \%)$ & $83.15(52.4 \%)$ \\
$29.60(33.0)$ & $30.38(30.6)$ & $31.17(25.0)$ & $33.40(21.0)$ \\
$15.18(17.5)$ & $17.26(17.4)$ & $22.59(18.1)$ & $28.75(18.1)$ \\
$0.28(0.3)$ & $0.58(0.5)$ & $2.47(2.0)$ & $5.39(3.4)$ \\
$5.34(5.9)$ & $5.79(5.8)$ & $6.84(5.5)$ & $8.04(5.1)$ \\
$90.04(100.0)$ & $99.27(100.0)$ & $125.14(100.0)$ & $158.72(100.0)$
\end{tabular}

注 2$) \mathrm{bbl} /$ 日 $\rightarrow \mathrm{t} /$ 年 (原油) : 50倍

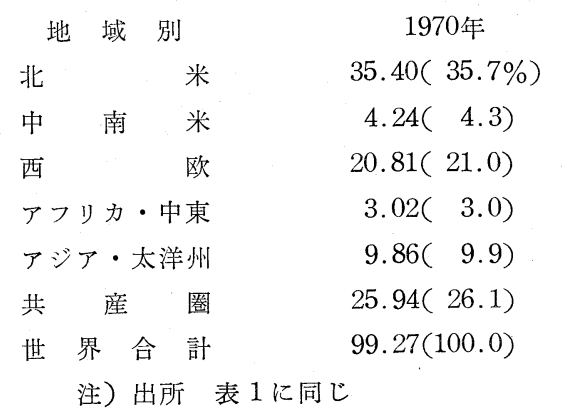

表 2 地域別エネルギーとアメリカ・ 1975年

1980年 42.91 ( $34.3 \%)$ $5.28(4.2)$ $52.55(33.1 \%)$ $26.01(20.8)$ $7.35(4.6)$ $4.08(3.3)$ $33.20(20.9)$ $5.75(3.6)$ $14.60(11.7)$ 20.05( 12.6) $32.26(25.8)$ $39.82(25.1)$ $125.14(100.0)$ $158.72(100.0)$ 
このことを裏付けるかのように「エネルギー政策の 中で安全性に必要以上の考慮を払うと低価格供給に影 響し, 経済政策の主目的である経済成長を弱めるか, 成長をとめてしまう」1)といら発言さえあった。

しかしわが国のように資源の大部分を海外に求好る 国ではエネルギーの安定供給は経済構造の基盤につな がることを噒みしめねばなるまい。昭和 50 年石油換算 10 億 $\mathrm{k} l$ におよぶ需要を一体何に頼り, どこに求めた らよいのであろらか。

いまこそわが国のエネルギー体制を「原点にかえっ て」見つめることが肝要であり, 従来の考えを超えた 「断絶の施策・技術」を求めてやまない。

\section{2. 世界のエネルギー需要とその資源量}

近時エネルギー需要の伸びは目覚しく, 各国とも見 直しがなされつつあり, 最近の世界の構成別, 地域別 エネルギー消費の見通しは次の表 1 , 表 2 のようにな っている。

世界のエネルギー消費を石炭換算でみると1960年44 億 $\mathrm{t}, 70$ 年70 億 $\mathrm{t}, 80$ 年には $110 \sim 120$ 億 $\mathrm{t}$ と予想さ れ，1970 80年では前10年の倍に近い40 50億 $\mathrm{t}$ のエ ネルギー増が見込まれ，これは石炭でいうと現在世界
石炭生産の倍に近い数量であり, 石油でいうと世界の $1 / 3$ を産出する中東産油量 (1970年 7 億 $\mathrm{t}$ ) の $4 \sim 5$ 倍の量に当る。

1969年日本，北米，西欧抢よびソ連（人口 9 億）で 石炭換算 55 億 $\mathrm{t}$ のエネルギーを消費, 1 人当り消費 6.1 $\mathrm{t}$ であるに対し，その他の国を全部合わせても（人口 27 億）その消費は 11 億 $\mathrm{t}, 1$ 人当り消費 $0.4 \mathrm{t}$ 亿過ぎ ない。しかし最近産油国の伸びは著しく, 従来の格差 が大きいだけに今後の開発途上国の伸長如何は将来の エネルギー需給バランスを大きく変える可能性を秘め ている。

これに対し世界のエネルギー資源量は表 3 のように なっており, 石炭類がその大半を占め, 現在のように 世界のエネルギーが石油・天然ガスに傾よればよるほ どエネルギー源はますますタイトになるであろう。

\section{3. 世界のエネルギーソース}

このような世界情勢の中で，わが国のエネルギーは 確保されね攵ならない。その意味ですでに周知のこと ではあるが，もら一度世界のエネルギーを種類別に整 理しながら眺めて見よう。

3-1 石油

需 要 予 測 ('68年実績)

\begin{tabular}{|c|c|c|c|}
\hline 1968年 & 1970年 & 1975年 & 1980年 \\
\hline 1,977 & 2,263 & 3,103 & 4,157 \\
\hline 1,485 & 1,519 & 1,558 & 1,670 \\
\hline 759 & 863 & 1,130 & 1,437 \\
\hline 14 & 29 & 124 & 270 \\
\hline 267 & 290 & 342 & 402 \\
\hline 4,502 & 4,964 & 6,257 & 7,936 \\
\hline
\end{tabular}

\begin{tabular}{rrrr}
\multicolumn{1}{c}{ 石炭換算 } & 100 万 $\mathrm{t} /$ 年 & \\
\hline 1968年 & 1970年 & 1975年 & 1980年 \\
2,768 & 3,168 & 4,344 & 5,819 \\
2,079 & 2,127 & 2,181 & 2,338 \\
1,063 & 1,208 & 1,582 & 2,012 \\
20 & 41 & 174 & 378 \\
374 & 406 & 479 & 563 \\
6,304 & 6,950 & 8,760 & 11,110
\end{tabular}

西欧エネルギー別需要予測（原油換算）

(単位：百万 $\mathrm{bbl} /$ 日)

$\begin{array}{lrrrr}\text { 燃 } & \text { 料 別 } \\ \text { 石 } & & & \text { 油 } \\ \text { 石 } & & \text { 炭 } \\ \text { 天 } & \text { 然 } & \text { ス } \\ \text { 原 } & \text { 子 } & \text { 力 } \\ \text { 水. 力 } & \text { 他 } \\ \text { 合 } & & \text { 計 }\end{array}$

アメリカ

1970年 1980年

$14.3(44.3 \%) \quad 21.0(43.9 \%)$

8.5( 17.7)

$6.5(20.1)$

$14.0(29.2)$

$10.2(31.6)$

$3.0(6.3)$

$1.4(3.3)$

1.1 ( 3.6$)$

47.9(100.0)

$\begin{array}{cc}\text { 1970年 } & \text { 西 } \underbrace{\text { 欧 }} \\ 11.81(56.8 \%) & 21.91(66.0 \%) \\ 5.60(26.9) & 4.10(12.3) \\ 1.30(6.2) & 3.40(10.3) \\ 0.30(1.5) & 1.60(4.8) \\ 1.80(8.6) & 2.00(6.6) \\ 20.81(100.0) & 33.21(100.0)\end{array}$


表 3 世界エネルギー埋蔵量

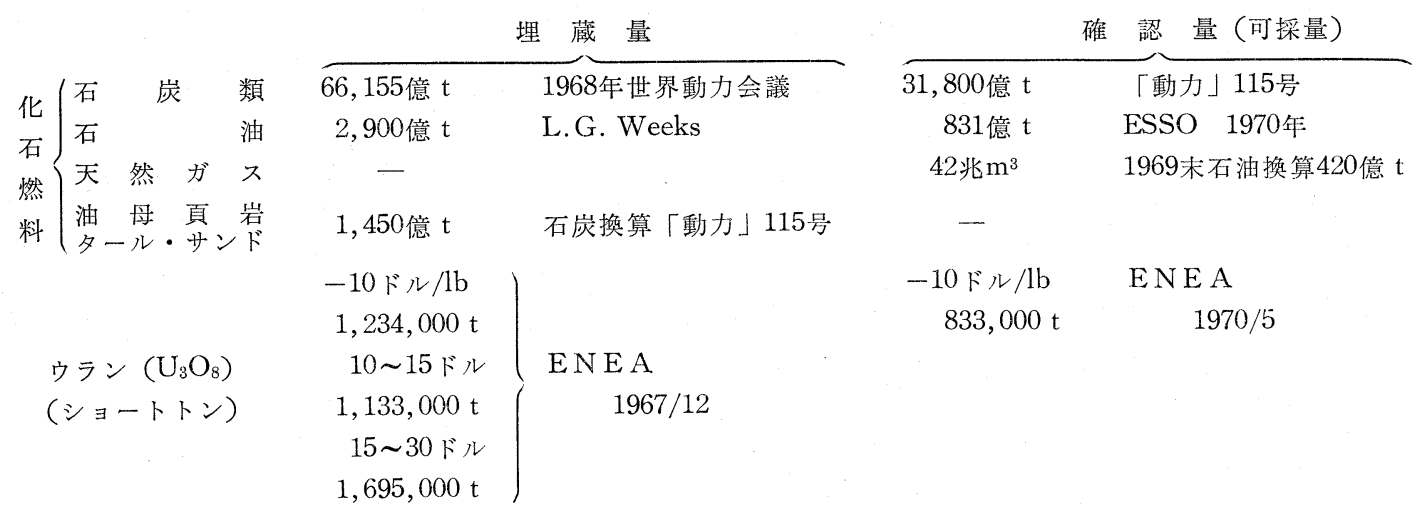

表 4 は地域別確認埋蔵量を示したもので, 中東が63 \%と大半を占为, 大きく東半球に片寄っているのが目 立つ。1969年末確認量は730億 $\mathrm{t}, \mathrm{R} / \mathrm{P} 32$ といわれ70 年末で 831 億 $\mathrm{t}$ と向上してきている。これは共産圈の 増加が大部分で, 新たに北海の石油発見が含まれてい る2)。

\section{表 4 地域別石油確認埋蔵量（1969年末）}

\begin{tabular}{|c|c|c|c|c|c|}
\hline $\begin{array}{lll}\text { 地 域 別 } & \text { 別国 }\end{array}$ & & $\begin{array}{l}\text { 埋蔵 量 } \\
\text { (百万彭bl) }\end{array}$ & $\begin{array}{l}\text { 比率 } \\
(\%)\end{array}$ & $\begin{array}{l}\text { 産油量 } \\
1969 \text { 年 } \\
(1000 \\
\mathrm{bbl} / \text { 日) }\end{array}$ & $\begin{array}{l}\mathrm{R} / \mathrm{P} \\
\text { (年) }\end{array}$ \\
\hline 北 & 米 & 43,822 & 8.3 & 12,305 & 9.8 \\
\hline ナ & ダ & 8,620 & & 1,078 & 21.9 \\
\hline メキシ & $\beth$ & 5,570 & & 411 & 37.1 \\
\hline アメリ & 力 & 29,632 & & 10,817 & 7.5 \\
\hline 南 & 米 & 24,761 & 4.6 & 4,638 & 14.6 \\
\hline ベネズエ & Eラ & 16,005 & & 3,594 & 12.2 \\
\hline 西 & 欧 & 676 & 0.1 & 339 & 5.5 \\
\hline 東 & 欧 & 60,074 & 11.4 & 6,938 & 23.7 \\
\hline y & 連 & 58,000 & & 6,545 & 24.3 \\
\hline ア ᄀ ע & カ & 46,950 & 9.0 & 5,067 & 25.4 \\
\hline アルジェリ & リア & 8,025 & & 974 & 22.5 \\
\hline エシ & $r$ & 3,000 & & 244 & 33.7 \\
\hline リビ & $p$ & 30,000 & & 3,109 & 26.4 \\
\hline ナイジエリ & リア & 5,000 & & 542 & 25.3 \\
\hline 中 & 東 & 329,641 & 62.6 & 12,630 & 71.5 \\
\hline アブ ダ & ビ & 15,000 & & 590 & 69.8 \\
\hline $1 \quad \overline{1}$ & ン & 55,000 & & 3,375 & 44.6 \\
\hline $1 \quad \overline{7}$ & ク & 28,505 & & 1,512 & 51.6 \\
\hline クウエー- & $-卜$ & 71,210 & & 2,575 & 75.8 \\
\hline 中立地 & 带 & 13,000 & & 428 & 83.3 \\
\hline オ - マ & v & 3,000 & & 360 & 22.9 \\
\hline- & ル & 3,900 & & 355 & 30.0 \\
\hline
\end{tabular}

$$
\begin{array}{crrrr}
\text { サウデアラビ } & 137,069 & & 3,216 & 116.8 \\
\text { ア } & & & \\
\text { 極東・太洋州 } & 20,869 & 4.0 & 2,251 & 25.4 \\
\text { インドネシア } & 18,000 & & 742 & 66.4 \\
\text { オーストラリ } & 1,827 & & 43 & 116.4 \\
\text { ア } & & & &
\end{array}
$$

世界 合 計 $526,791 \quad 100.0 \quad 44,168 \quad 32.7$

注）World Oil，1970年 8 月15日号

世界の石油需要は 1970 年 23 億 $\mathrm{t}$ を消費, 75 年 31 億 $\mathrm{t}, 80$ 年 41 億 $\mathrm{t}$ 亿達すると予想され, 今世紀中はます ます石油への期待が増大するといわれている。ここ10 年の増加分 18 億 $\mathrm{t}$ は, 現在中東生産量の 3 倍に近い量 であり, アラスカ油田の推定供給量 1.25 億 $\mathrm{t} /$ 年 ${ }^{3)}$ の 10数倍の莫大な量である。

1990年までの世界石油消費は約 800 億 $\mathrm{t}$ といわれ, これは現在確認量と匹敵する量であり, R/P15で満足 できると仮定してもこの間約 800 億 $\mathrm{t}$, 現在の $\mathrm{R} / \mathrm{P} 30$ を維持するとすれば実に 1,800 億 $\mathrm{t}$ の新油田を発見せ ねばならないことを意味する4)。

表 5 はメジャーの15年後の R/P の変化予想である が，生産は依然として東半球に偏重し，その $\mathrm{R} / \mathrm{P}$ も 51 か 16 に抢ち, 全体を16 と現在の半分になり新規油 田発見のむずかしさを物語っている。

表 $5 \quad \mathbf{R} / \mathbf{P}$ の変化予想 1970 年 $R / P \quad 1985$ 年 $R / P$

$\begin{array}{lrrr}\text { アメ リ } & 9 & 10 \\ \text { カナダ, 中南米 } & 18 & 21 \\ \text { 東 半 球 } & 51 & 16 \\ \text { 共 産 圈 } & 21 & 16 \\ \text { 世界平 均 } & 32 & 16\end{array}$

富館孝夫：メジャ一の見通し，

エネルギー 1971年 4 月 
いずれにせよ，産油国の高姿勢が強まるにつれ，国 際石油国のこれらの国への投資は減り，その力を新規 油田（北極圈・西アフリカ・極東）の開発に投入し, これによって産油国をけん制する方向に進むだろう。

一方公害防止の兒地から低イオウ原油（現在自由世 界生産の $40 \%$ ） への要求はますます高まりつつある。

これらを考えあわせると，「結局われわれは激しい 欠乏の時代，そして最終的に浽縔的に入手できる石 油資源が枯渴してしまう時代を通ることになるである う」らうといら言葉の現実性がひしひしと感じられる。

現在世界の石油生産体制は大きくは国際石 油企業 (メジャーズ), 独立系企業（マイナーズ）㧍よび国策 会社に分かれ，メジャ一の占为る割合は1968年で生産 $65.5 \%$, 精製 $59.4 \%$, 販売 $57.5 \%$ となっている。

これに対し産油国側の最大機構である OP E C は発 足以来結束を固め, 1970年 9 月リビヤの值上げに端を 発し, 12月のカラカス会議, 71年に入ってテヘラン, トリポリ協定と次第にその主張を通し，いまや洒格の 主導権はOP E C 側に移った感がある。

表 6 は1970年の自由世界の推定産油量を示したもの

\section{表 61970 自由世界原油生産量と OPEC の比重}

\begin{tabular}{|c|c|c|c|}
\hline \multicolumn{2}{|c|}{ 国 } & \multicolumn{2}{|c|}{ 名 } \\
\hline ア & x & & 力 \\
\hline 力 & & - & ダ \\
\hline 北 米 & 小 & 計 & (A) \\
\hline ベ & 京 & $8=$ & ラ \\
\hline 中 & & & 東 \\
\hline リ & & $=$ & ア \\
\hline アル & ジ & I & ア \\
\hline 1ン & ド & ネ & \\
\hline
\end{tabular}

OPEC小計 (B)

自由世界計 (C)

$\mathrm{B} / \mathrm{C}$

(\%)

$\mathrm{B} /(\mathrm{C}-\mathrm{A})(\%)$

(単位: 百万 $\mathrm{t}$ )

生産量

534

69.5

603.5

193

703.8

159

46.4

45

$1,147.2$

$1,941.4$

60

85

注） P P S 日本語版 1971年 1 月

で, OP E Cの比重は自由世由の $60 \%$, 北米を除くと 実に $85 \%$ に達している。1960 年の O P E C の石油収 入6) は中東 3,763 百万ドル，リビヤ 1,132 百万ドル， ベネズエラ 1,289 百万ドルなど合計 6,094 百万ドルで あり,これに対し 7 大メジヤ一の純益忙合計 4,781 百 万ドルであった。表 7 は今回の值上を公示価格と実勢

\section{表 7 原油公示価格と坑井元実勢価格の推移}

生産地銘柄別

\begin{tabular}{|c|c|c|c|c|c|c|}
\hline \multirow{2}{*}{\multicolumn{2}{|c|}{ 生産地 銘柄 別 }} & \multicolumn{5}{|c|}{ 公示価格 } \\
\hline & & \multicolumn{2}{|c|}{ 攻勢前 } & \multirow{2}{*}{\multicolumn{2}{|c|}{$\begin{array}{l}\text { 1971年協定 } \\
2.125 \text { (130) }\end{array}$}} & \multirow{2}{*}{$\begin{array}{c}1975 \text { 年 } \\
2.553 \text { (156) }\end{array}$} \\
\hline イラニアン・ヘビー(API & $\left.31^{\circ}\right)$ & 1.63 & $(100)$ & & & \\
\hline アラビアン•ライト( & $\left.34^{\circ}\right)$ & 1.80 & $(100)$ & 2.18 & (121) & $2.614(136)$ \\
\hline ナイゼリア原油 （"） & $\left.34^{\circ}\right)$ & & & 3.212 & & 3.85 \\
\hline リビア原油 & $\left.40^{\circ}\right)$ & 2.230 & $(100)$ & 3.447 & (155) & 4.13 (185) \\
\hline ゼリア & $\left.44^{\circ}\right)$ & & & 3.6 & 方的 & 4.32 \\
\hline
\end{tabular}

（単位：ドル/bbl（）:上昇率\%）

\begin{tabular}{ccc}
\hline 攻勢前 & 1971年前期 & 1975年 \\
$1.24(100)$ & $1.65(133)$ & $1.91(154)$ \\
& 1.74 & \\
& 2.43 & \\
& 2.62 &
\end{tabular}

注 1) 実勢価格は值上り分消费者負担時推定值

価格で示したもので, 積地実勢価格で21 55\%の值上 となり,さらに 5 年間の值上が約束されている。これ による中東 6 力国の収入増は1971年平均で 14400 百万 ドル， 75 年で 3,260 百万ドルとされる。消費者価格も すでに昨年より高騰を続け, アメリカの燃料油は昨年 中に約 2 倍の $25 \sim 30$ ドル/ $\mathrm{t}$ と值上りをし, わが国で も10.000円台の重油も現われ, 今回值上分のほとんど が消費者に転稼されつつある。

石油事業は莫大な投資を伴い，チエス・マンハッタ ン銀行によれば自由世界の石油産業への総投資額は, 1968年192億ドル，1969年198億ドルで伸率の低下が見 えはじめた。表 8 注最近数年の石油産業投資額と年産 bbl 当りの投資を示しており?, 探鉱開発部門が約半 分を占め, アメリカ系が自由世界の約 $70 \%$ を投資して
注 2）日本エネルギー経済研究所資料より

いる。バレル当り探鉱・開発投資では地域差が目立 ち, 平均年産 $\mathrm{t}$ 当り 0.7 ドル程度である。

各国の開発の動きを見ると, アメリカメジヤーの活 動は周知のとおりであり, 注目されるアラスカのノ一 ススロープは推定埋蔵 80 億 $\mathrm{k} l$, 生産量 $1 \sim 1.5$ 億 $\mathrm{t} /$ 年8) と予想され, 本国向け供給に予定される。

イギリスは B.P (国家資本 $50.5 \%$ ), ダツチシエル （オランダとの合弁）を中心にエツソが加わり, 大陸 柵および海外開発を行なっており, 北海では地質調查 所石炭庁, ガス公社と協同して天然ガス, 石油の探鉱 開発を続け, 大陸柵開発の一方向を示している。

フランスは国策会社 ERAP/ELF と民間の CEP （メジヤーの一つ）が担当して自由開発を進め, ラッ クガス油, アルゼリヤの石油・天然ガスの発見開発な 


\section{表 8 石油産業部門別投資 $(A)$ と年生産 $\mathbf{b b l}$ 当り 探鉱開発投資 $(\mathbf{B})$}

A 石油産業部門別投資（自由世界）(単位:百万ドル)

\begin{tabular}{|c|c|c|c|c|}
\hline 年 & 1960 & 1967 & $\begin{array}{c}1968 \\
\text { (内アメリカ) }\end{array}$ & 1969 \\
\hline $\begin{array}{l}\text { 探 } \\
\text { 鈗 } \\
\text { 開 }\end{array}$ & $6,795\}$ & 7,190 & $\left.\begin{array}{l}1,330(715) \\
7,460(4,925)\end{array}\right\}$ & 8,92 \\
\hline $\begin{array}{l}\text { Pタク } \\
\text { タンカー }\end{array}$ & 1,660 & 2,140 & $2,755(\quad 475)$ & 3,000 \\
\hline 精 製 & 1,130 & 2,585 & $2,950(800)$ & 0 \\
\hline 販 売 & 1,425 & 2,705 & $2,665(1,150)$ & 2,805 \\
\hline 由化学代 & 700 & 2,145 & $2,070(1,000)$ & 1,820 \\
\hline 計 & 1,610 & 16,765 & $19,239(9,065)$ & 19,755 \\
\hline
\end{tabular}

$\mathrm{B}$ 年生産 $\mathrm{bbl}$ 当り探鉱開発投資

\begin{tabular}{|c|c|c|c|c|c|c|c|}
\hline 年 & $\begin{array}{l}\text { アメ } \\
\text { リカ }\end{array}$ & $\underset{\text { ガ }}{\text { カナ }}$ & $\begin{array}{l}\text { ベネズ } \\
\text { エラ }\end{array}$ & $\begin{array}{l}\text { アフ } \\
\text { リカ }\end{array}$ & & 極 & 界計 \\
\hline & 1.65 & 1.91 & 0.14 & 0.70 & 0.07 & 0.99 & 0.83 \\
\hline 965 & 1.5 & 2.31 & 0.15 & 0.54 & 0.14 & 0.88 & 0.77 \\
\hline & 1.45 & 2.34 & 0.18 & 0.42 & 0.08 & 0.44 & 0.68 \\
\hline & & 1.99 & 0.10 & 0.37 & 0.09 & 0.73 & 0.64 \\
\hline & & & .14 & 0.38 & 0.08 & 0.77 & $0 .^{\prime}$ \\
\hline
\end{tabular}

注）チェス・マンハッタン銀行

ど戦後営々と築いてきた努力の結晶が実りつつある。 しかし現在值上，国有化問題でフランス需要の $25 \%$ を 受けもつアルゼリアの石油が輸入中断状態にあり, こ れからの海外開発の一面を物語っている。

イタリアは国策会社ENIが中心となって石油, 天 然ガス, ウラン開発を主導し, ポー河, アドリア海, アフリカなどで活躍し実績をあげている。

出遅れた西ドイッも1969年国内 8 社の結集によりデ ミネックスを設立，自給率 $25 \%$ 目標に $75 \%$ 成功払な ぞ強力な政府の財政援助のもと活動を開始し, 最近日 本に共同開発を申し入れている。

一方産油国側はナショナリズムの昂揚, 自国経済へ の貢献をモットーに事業参加, 生産割当制実施, 資源 保全を共通目標洫ますますその力を增してくると予想 され，このような世界情勢の中で日本は総エネルギー 需要の70\%を石油に頼ろらとしている。

\section{3-2 天然ガス}

天然ガスも世界のエネルギーの中で1950年10\%から 70 年 $17 \%$ と急速に伸び，今後は $18 \%$ 台を維持するだろ らとされわが国でもこれからきれいなエネルギーと して大いに期待されている。

世界の確認量は 42 兆 $\mathrm{m}^{3}$ (石油換算 420 億 $\mathrm{t}$ ) とさ れ, その後急激増えており 100 兆 $\mathrm{m}^{3}$ といら説もあ る。表 9 は世界の地域別消費予想を示している。

\section{表 9 世界天然ガス需要予測}

（単位：兆 $\mathrm{ft} /$ 年 $\left(10\right.$ 億 $\mathrm{m}^{3} /$ 年))

1965年 1970 年 1980 年

$\begin{array}{crrrr}\text { 北米 } & 17.1(485) & 21.7(615) & 28.6( & 810) \\ \text { 西欧 } & 0.8(23) & 2.0(57) & 3.9( & 110) \\ \text { 共産圈 } & 5.2(148) & 9.6(271) & 13.0( & 368) \\ \text { その他 } & 1.2(34) & 1.8(51) & 2.5( & 71) \\ \text { 世界計 } & 24.3(690) & 35.1(994) & 48.0(1,359) \\ \text { 注) } & \text { Oil \& Gas J. } & \text { 1967年 6月 } & & \end{array}$

世界の主要な天然ガス源を見ると，アメリカは天然 ガスの元祖であり 1969 年総エネルギーの $1 / 3$ 亿近い 5,900 億 $\mathrm{m}^{3}$ を生産してきたが, 最近 R/P も13におち (確認量 8 兆 $\mathrm{m}^{3}$ ) カナダはもちろん北アフリカからの 輸入も予定され，80年ではその割合も $1 / 5$ 亿扔ちると も予想されている。これから注目されるのはアラスカ ・クック，ノース・スロープ (推定量 8 兆 $\left.\mathrm{m}^{3}\right)$ であり, すでにクック湾からの L NG G横浜根岸向に開始さ れ, 年閒96万 $\mathrm{t}$ の輸入契約がわが国と結ばれている。 西欧ではオランダのフローニンゲン (確認量 2 兆 $\mathrm{m}^{3}$ ) にはじまり, フランスのラック,イタリアのポー, ア ドリヤ海，イギリスの北海（推定量 3 兆 $\mathrm{m}^{3}$ ) など天然 ガスが西欧エネルギーの重要なソースとなってきた。 しかしながらこれも最終 8 \%程度の寄与率とされる。 北アフリカはアルゼリアが主力であり, その量 4 兆 $\mathrm{m}^{3}$ といわれハシ・ルメルガス田を中心に開発され， LNGとして西欧に輸出され，リビヤ，イランなどを 含め, 日本にとってこれからの輸入源として期待され る。

ソ連のガス田はチューメン（推定量 15 兆 $\mathrm{m}^{3}$ といわ れる）をはじめ欧州からシべリアにわたり賦存してお り，最近サハリンとともにチューメンからのガス輸送 が石油も含めわが国で論議されている。

東南アジア，大洋州ではブルネイ(アンパアガス田) から L NGとして日本一年 365 万 $\mathrm{t}$ の供給が契約され ており，さらにサラワク沖でもこれに優るガス田が発 見された。また最近ではオーストラリアの天然ガスが 石油とともに注目されている。(バス海峽外)

開発体制は各国ほぼ石油と同じである。

価格は石油の高騰, 開発促進のため上昇してきてお り, 西欧の坑井価格は $27 \sim 36$ セント/tcf（3.4 4.5円 $\left./ \mathrm{m}^{3}\right)$, 輸入 $\mathrm{L} \mathrm{NG}$ は地中海岸で $38 \sim 40$ セント/tcf, ペ ルシャ湾岸で 52.5 セト/tcf とされる。アメリカでの 輸入 L NGの価格はベネゼエラ 43.75セント/tcf, アル

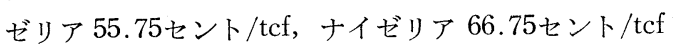
となっている。（注 $\mathrm{tcf}=1,000 \mathrm{ft}^{3}$ ) 
日本の輸入 L NGはアラスカ 59 セント/tef (7.4円/ $\left.\mathrm{m}^{3}\right)$, ブルネイ 55 セント $/ \mathrm{tcf}\left(6.9\right.$ 円 $\left./ \mathrm{m}^{3}\right)$ といわれ遠 距離, 液化のためかなり高い。

3-3 石炭

表 10 は主要国の埋蔵量を, 表 11 はその生産量・予 想を示している9)。この表でもコークス用炭の炭量は $1 / 5$ 程度で，治金用コークス用炭になるとさらにその 量は激減する。アメリカの例では全炭量, 1.5 兆 $\mathrm{t}$ の らちコークス用炭 2,560 億 $\mathrm{t}$, 治金用コークス用炭 1,010億 $\mathrm{t}$, 強粘結炭に至っては 98 億 $\mathrm{t}$ に過ぎない、 しかも良質原料炭は先進国に集中している。世界のコ 一クス用炭の需要は，1965年 437.4 百万 $\mathrm{t}, 69$ 年 463.7 百万 $\mathrm{t}, 75$ 年 538.5 百万 $\mathrm{t}{ }^{10)}$ と需要増が予想され, 今 後とも良質コークス用炭の競合は続きそうである。

表 10 特定国別推定石炭埋蔵量(褐炭含む全石炭類) (単位 : 10億 $\mathrm{t}$ )

\begin{tabular}{|c|c|c|c|}
\hline & & 全石炭 & 広義コークス用炭 \\
\hline ア メ リ & 力 & 1,505 & 256 \\
\hline カ ナ & ダ & 87 & 17 \\
\hline コロンビ & $\boldsymbol{\gamma}$ & 12 & 3 \\
\hline ド イ & ツ & 286 & 74 \\
\hline イギリ & ス & 171 & 56 \\
\hline ポーラン & ド & 80 & 22 \\
\hline フ ラ ン & ス & 13 & 4 \\
\hline 南 & ア & 68 & 19 \\
\hline オーストラリ & ヤ & 58 & 6 \\
\hline У & 連 & 1,200 & 220 \\
\hline 中 & 国 & 1,011 & 223 \\
\hline ン & ド & 63 & 14 \\
\hline 日 & 本 & 10 & 4 \\
\hline 計 & & 4,564 & 918 \\
\hline
\end{tabular}

注）アメリカ地質調査所

オキシデンタル・ペトロリウム市場調査部

逆に褐炭・亜稚青炭・高揮発分瀝青炭は莫大な量に のぼり, かつ世界各地に存在し, 露天掘をはじめ 2 3 ドルで採掘できる炭田がまだまだ多量にあると思わ れインフラストラクチャーを別にすれば開発費も安い 所が多いと思考される。

いずれにせよ，この世界のエネルギー不足に対処す るには量的にも圧倒的な石炭の活用にもっと真剣に取 り組むべきではなかろらか。

\section{3-4 原子力}

ウランは濃縮エネルギーとしては現在最高のもので ある。自由世界の 10 ドル以下の酸化ウランの確認量は

\section{表 11 主要国石炭・褐炭生産}

(歴青炭・無煙炭) (単位 : 百万 $\mathrm{t}$ )

$70 \sim 80$

1965年 1969年 1970年 1980年 成長率

アメリカ $\quad 475.3 \quad 510.0 \quad 533.0 \quad 752 \quad 3.5 \%$

$\begin{array}{llllll}\text { カナダ } & 8.7 & 7.9 & 10.3 & 19 & 6.3\end{array}$

$\begin{array}{llllll}\text { E C S C } & 218.0 & 171.8 & 167.0 & 180 & 0.8\end{array}$

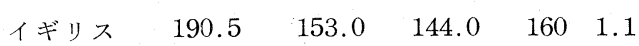

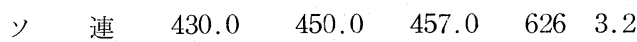

$\begin{array}{llllll}\text { ポーラン } & 118.9 & 135.0 & 138.0 & 195 & 3.5\end{array}$

中 国 $300.0 \quad 325.0 \quad 320.0 \quad 360 \quad 1.1$

インド $\quad \begin{array}{llllll}67.2 & 70.5 & 71.5 & 80 & 1.2\end{array}$

$\begin{array}{lllllll}\text { 日 } & \text { 本 } & 40.5 & 44.7 & 41.5 & 40 & \text { - }\end{array}$

$\begin{array}{lllllll}\text { 南 } & \text { ア } & 48.5 & 52.0 & 53.6 & 64 & 1.8\end{array}$

$\begin{array}{llllll}\text { オースト } & 31.9 & 44.0 & 49.0 & 69 & 1.2\end{array}$

その他 $\quad \begin{array}{llll}110.3 & 119.5 & 120.3 & 134\end{array}$

$\begin{array}{lllll}\text { 世界計 } 2,048.8 \quad 2,083.4 & 2,105.2 & 2,679 & 2.4 \%\end{array}$

(褐炭)

ヨーロッ $704.5 \quad 706.0 \quad 710.0 \quad 785 \quad 1.0 \%$

その他 $29.9 \quad 36.5 \quad 39.6 \quad 53$

世界計 $734.4 \quad 742.5 \quad 749.6 \quad 838 \quad 1.1 \%$

注）出所表 10 に同じ

100 万 $\mathrm{t}$ といわれ，これに対し世界の需要は69年 1.6 万 $\mathrm{t}, 80$ 年 7.3 万 $\mathrm{t}, 85$ 年で 13 万 $\mathrm{t}$ 累計 100 万 $\mathrm{t}$ を超える とされる。生産高は一時 4.4 万 $\mathrm{t}$ に達したが，その後 激減, ストックパイル政策などにより69年 3.8 万ま で回復した。

価格（アメリカ）はポンド当り現在の 6 ～6.25ドル が75年には 8 ドル，80年には10ドルを超すと予想され $\mathrm{U}_{235}$ に頼る限り資源は限られ, 新型転換炉 (A T R), 高速増殖炉（F B R ）の開発が急がれている。

自由世界では表 12 に示すように, アメリカ, カナ ダ, 南アで埋蔵量の $80 \%$ を占め, 生産量は70年でアメ リカ $49.3 \%$, カナダ $19.3 \%$, 南ア $16.0 \%$, フランス $6.8 \%$ である。自由世界では米系 15 社, NUF (南ア), デニソン (カナダ), リオチント (イギリス), C E A （フランス）がほとんど支配し，他国企業の進出はな かなかむずかしいとされる11)。

アメリカは当初のC D A か 1961年民有化, カーマ ギー, ユナイテッド・ニユークレア， ウエスタン・ニ ュークレアなど15社でほとんど開発され，A E C の強 力な保護をらけている。

カナダは国営のエルドラド, 民営のデニソン, リオ 


\begin{tabular}{|c|c|c|}
\hline \multicolumn{3}{|c|}{$\begin{array}{l}\text { 表 } 12 \text { 自由世界ウラン埋蔵量 } \\
\left(-10 \text { ドル/ポンド } \mathrm{U}_{3} \mathrm{O}_{8} \text { ショート・トン }\right)\end{array}$} \\
\hline 国 & 埋蔵量 & $\%$ \\
\hline フランス & 45,000 & 5.4 \\
\hline 1 タリ & 1,500 & 0.2 \\
\hline ポルトガル & 9,500 & 1.1 \\
\hline ス ヘ 1 ン & 11,000 & 1.2 \\
\hline 下 ル & 2,500 & 0.3 \\
\hline ユーゴスラビア & 1,300 & 0.2 \\
\hline アルゼンチン & 10,000 & 1.2 \\
\hline オーストラリア & 21,700 & 2.6 \\
\hline アメリカ & 250,000 & 29.5 \\
\hline カ ナ ダ & 232,000 & 27.7 \\
\hline 中央アフリカ & 10,400 & 1.2 \\
\hline ガボ & 13,500 & 1.6 \\
\hline 日 & 2,700 & 0.3 \\
\hline メ $\neq シ$ シ & 1,330 & 0.2 \\
\hline 二シエ-ル & 26,000 & 3.0 \\
\hline 南 & 200,000 & 24.0 \\
\hline 計 & 838,000 & 100.0 \\
\hline
\end{tabular}

注) ENEA 1970/5

アルゴム（リオチント系）の 3 会社が主力である。 イギリスは原子力会社（現在民間移行中でBNF発
足）を中心にリオチント社ほかカナダ, 南ア, オース トラリアで活躍中である。

フランスはC E Aがすべてを掌握し，第 4 位のウラ ン資源国とまでなり, 海外でも積極的な探鉣を進め, ニジェール（2.6万 $\mathrm{t}$ 以上）を発見, 西ドイッ, 日本 とも共同開発を開始した。C E A 自らも出資, 現地, 民間と現地法人を設立, 販売保証を与えている。

イタリアは EN I が統括し，海外ではソマリン，ケ ニヤ鉱区を取得, デニソンと組み各地で探鉱している。 西ドイッも開発輸入目標を $80 \%$ に最近引き上げ, ウ ランゲゼルシャフトーウランエルツベルグバウを設 立, 強力な政府援助をうけ積極的に乗り出してきた。 南アは1967年民有が認められ持株会社 NUFCOR のもとアングロアメリカン, ゼネラルマイニング，ア ングロトランスバール，ランドマインズおよびリオチ ントが支配的である。このほか金の副産物として生産 されている。

\section{4. わが国エネルギーの最近の動き}

確かにエネルギ一の低廉安定供給を基盤として，わ が国の経済は驚異的成辰をなしとげ将来への産業構造 を形成した。一方このため将来に向って，表13のよ らなぼう大なエネルギーが要求され, 資源確保こそ日 本の「アキレス腱」だといわれている。そのため諸施 策や計画が実行に移され具体化されようとしている。

\section{表 13 日本長期エネルギー需給バランス（昭和 60 年）要供給ベース}

$$
\text { エネルギー種別 }
$$

\begin{tabular}{|c|c|c|}
\hline 石 & 油 & (百万 $\mathrm{k} l$ ) \\
\hline 石 & 炭 & （百万 $\mathrm{t}$ ） \\
\hline 5 & ち原料 炭 & $(\prime \prime))$ \\
\hline 天 & ガ & $\left(\right.$ 百万 $\mathrm{m}^{3}$ ) \\
\hline $\mathrm{L}$ & $\mathrm{N}$ & （百万 $\mathrm{t}$ ) \\
\hline 原 & 子 & (10億 $\mathrm{kWhr}$ ) \\
\hline 水 & 力 & ( 11 \\
\hline 石 & 油 & (1013 kcal) \\
\hline 石 & 炭 & $(1)$ \\
\hline 天然ガス & (含 $\mathrm{LNG}$ ) & $(1)$ \\
\hline 茞 & 子 & ( $\prime \prime$ \\
\hline 水 & 力 & $(1)$ \\
\hline 7 & の & $(\prime \prime)$ \\
\hline 合 & 計 & ( 11 \\
\hline
\end{tabular}

注）昭和 45 年 総合エネルギー調查会
一次エネルギー供給

\begin{tabular}{ccc}
\hline 国内生産 & 輸 & 入 \\
6.3 & $718.0 \sim 801.8$ & $724.3 \sim 808.1$ \\
37.0 & $188.0 \sim 209.1$ & $225.0 \sim 246.1$ \\
12.6 & $185.7 \sim 206.7$ & $198.3 \sim 219.3$ \\
$10.7 \sim 10.8$ & - & $10.7 \sim 10.8$ \\
- & 10.4 & 10.4 \\
406.6 & - & 406.6 \\
$100.9 \sim 103.8$ & - & $100.9 \sim 103.8$ \\
5.0 & $672.4 \sim 750.7$ & $678.3 \sim 756.6$ \\
22.1 & $144.7 \sim 161.0$ & $166.8 \sim 183.1$ \\
10.5 & 13.8 & 24.3 \\
99.6 & - & 99.6 \\
$24.7 \sim 25.4$ & - & $24.7 \sim 25.4$ \\
1.8 & $8.5 \sim 9.3$ & $10.3 \sim 11.1$ \\
$164.6 \sim 165.3$ & $835.2 \sim 930.2$ & $999.8 \sim 1,095.5$
\end{tabular}


海外エネルギー事情調査団の中間報告は

(1)石油の低廉安定確保のための分散化と石油資源の

探查開発およびその円滑化のための海外経済協力

(2)わが国原油輸入の自主性確保とその措置

(3)脱硫の促進と天然ガスの活用

(4)備蓄政策の確立

(5)日本の石油企業亡くに民族資本系企業の体質強化

(6)原子力開発の強力推進

がその骨子としてあげられている。

一方海外経済協力審議会の答申は昭和50年, 国民生 産の $1 \%$ (約 1.5 兆円) を海外投資す心゙きだとし, そ の体制強化のため省また庁の設立を答申している。

通産省案によると46〜50年の 5 年間の海外資源開発 投融資は50億ドルとされ，海外総投融資の半分にあた る。エネルギ一関係では石油・ガス 7,400 億円, 原料 炭 1,500 億円， ウラン・ニッタル・ボーキサイト 2,400 億円となっている。

また海洋開発についても日経連は日本経済調査協議 会で今後10年の投資額をまとめ, 資源開発関係では海: 洋石油・ガス開発 33,130 億円, 海底鉱物 6,640億円, 海洋エネルギー3, 670億円, 海洋工事用特殊船 5,800 億 円があげられている。

つぎにエネルギー別の動きを見てみよう。

4-1 石油・天然ガス

石油開発公団が中心となり最近石油界とくに民族系 企業の動きが活発となり,同公団を軸とするアブダビ, カタール, 合同, ノース・スロープ, アラスカの合同 など新体制への動きが高まってきている。

通産省も答申の主旨に基亏゙き石油開発の方針を内定 (1)石油資源開発への諸金融措置

(2)大規模プロジェクトの推進

(3)備蓄一の石油税を財源とする特別会計（45日 $\rightarrow 60$ 日）

(4)石油開発公団の拡充 : 直接利権の獲得, 原油引取 り

(5)民族系企業の育成：ひもつき資本の返済 $(7 \sim 8$ 年で完済, 46年度 150 億円)

(6)情報・技術開発の強化

を骨子とし，46〜50年で6,400億円と備蓄1,000億円が 提案されている。

4-2 不炭

わが国の石炭鉱業は悪条件にもかかわらず，すでに 生産性ではヨーロッパ第一を誇る西ドイッと有をなら ベ，厚層採掘，傾斜採炭，海底採掘，ガス対策などに 独自の技術を開発してきた。もちろん条件に恵まれた
米・豪・加に比べると能率は劣ってはいるが，日本の 技術を結集すればこれら石炭開発国において負けない 力を発揮できる技術水準にあると思われる。

これからの日本の石炭鉱業のあり方としては, 莫大 な世界の石炭埋蔵量を生かす意味でも, 国内炭の変動 に対処するためにも，ここまで育てた技術を活用する ためにも，国内，海外を組合せた企業形体で進むべき であり，このような国の方策を期待するものである。

石油開発技術で経験されるように一日にして技術は 成るものではないことを忘れてはならない。

\section{4-3 原子力}

総合エネルギー調查会原子力部会の中閒報告によれ ば昭和 55 年のウラン $\left(\mathrm{U}_{3} \mathrm{O}_{8}\right)$ 所要量は $9,000 \mathrm{t}$ （昭 和 45 年以降累計 $46,000 \mathrm{t}$ ) 昭和 65 年 $14,000 \mathrm{t}$ （累計 106,000 t）が予想され，これに対しわが国の現在確 認量は $8,000 \mathrm{t}$ であり, どうしても海外に求めねばな らない。

そのためウラン所要量の $1 / 3$ の開発確保を目標とし て10年閒で 420 億の探鉱開発資を投入する方針で

(1)金属鉱物探鉱促進事業団，海外経済協力基金定通 じての低利融資, 成功払などの財政措置

(2)有望鉱区の買収, 合弁事業資金への長期低利融資, など強力な政府資金を導入することにより民間企 業を援助しようとしている。

ウランについては電力会社が外国と長契を結んでい るほか, フランスからのニジェールの共同開発の申入 れを期に海外ウラン資源開発株式会社が設立され，こ こが中心となって進もらとしている。最近イタリヤ， 西ドイッも共同開発を申し人れてきており, 今後の活 躍が期待される。

\section{5. 施策 の 要}

いまほどわが国のエネルギ一施策に真の裹付が必要 な時はあるまい。施策のいかんではGN P の誇りを失 らことにもなりかねない。

5-1 エネルギー確保は果して可能か

このよらなエネルギー事情の中で果してこのぼう大 なエネルギーを確保できるであろらか。昭和60年で石 油だけみても現在の 3.5 倍におよぶ 7 億 $\mathrm{k} l$ の石油を大 手せ衩ばならない。しかも世界の資源国をもって任じ るアメリカはもちろん, ソ連でも近い将来石油の輸入 国になるともいわれ(2)，この中で総エネルギーの70\% を石油に頼ることに無理はないであろうか。

国際石油企業団はいらにおよばす，ERAP，ENIに しても長年の努力の結実にほかならないことを忘れて はならない。脱工業化が叫ばれ，量より質へ産業構造 
の変換が論ぜられいるが，一朝一夕になるものではな い。新エネルギーの活用, 省エネルギー化をはかりな がら変換を行ならべきであろう。そのためにも自らの エネルギーは自ら掝み自ら解決せ补ばならない。

5-2 エネルギーの共存共栄

世界的エネルギー不足時代に対処するためには「将 来われわれの天然資源の管理はますます集中化し，協 同化し，合理化されるであろう。いまやお互に競争し 合うよりも，あらゆるエネルギーについて補い合うこ とが必要となっている」13) といわれている。

確かに世界の事情は醜いエネルギ一戦争を避けるた めにも，エネルギー種別間，産業別間，生産者消費者 間, 資源国輸入国間, 先進国開発途上国間が互に助け あらエネルギーの共存共栄の時代に入つたことを認識 すべきであろら。

4-3 エネルギー源をもら一度見つめよう

コンチネンタル・オイル社長マクリーン氏は「地球 の殼の中の流体炭化水素は限られており, 一方われわ れは無限に近く伸びる需要をこれに求めている。した がって最終的には石炭, 油母頁岩, タールサンド, 原 子力その他あらゆる形のエネルギーを利用するように なるであろら。しかもその時期は意外に早いにちがい ない」といっている5。

確かに資源にそしいわが国では海洋資源も含めもう 一度世界のエネルギー源を見直す必要があろら。

(1)石炭類

前述のように埋蔵量としては化石燃料の大半を占 め, 治金用コークス用炭以外に採掘費の安い褐炭・亚 瀝青炭を含む高揮発分炭が世界各地に多量に分布して おり, 中国, 東南アジャ, 豪州, シベリアなど日本の 近くにも大量に賦存している。

絶対的資源量を誇りながら近来石炭が斜陽化されて いる原因は,一つに固体と流体の格差にほかならない。 従って石炭を安く流体化することさえできれば, 現在 のエネルギー緊張を大きくゆるめることができよう。

アメリカの70年代の流体化をはじめとする石炭新利 用への一連の動きは, 将来の石炭需要を左右する大き な「鍵」といえよう。

(2)海洋エネルギー

イギリスが海中ウラン採取に，北海のガス・石油開 発に懸命に取り組んでいるように，フランスが潮汐発 電やプレコンチナン計画を押し進めているように海国 日本としても何かエネルギーのバックボーンとなりら る海洋エネルギーの実用化に打ち込むべきであろう。 5-4 エネルギーに弾力性・融通性を
エネルギーの相互協調のためにも，非常に変動が多 いだけに弾力性, 融通性をもたせ, 臨機応変の体制を とらねばなるまい。すなわち備蓄はもちろん, 石炭兼 燒発電, 原子力の多目的利用, 原料の転換態勢, パイ プラインの互換性など多少設備投資はかさんでも，変 動時に対応する力をエネルギー構造にもたすことが是 非必要である。

5-5 原料地生産

最近資源国の原料供給から一次製品輸出への転換の 要望は次第に強くなつている。海外経済協力の立場か らも, 省エネルギー, 脱工業化の意味からも一次製品 の原料地生産に踏み切り，国内産業を高度化する時期 が到来したのではなかろうか。石油精製, 鉄鋼などの 現地生産を行なえば, フレートの節約, 船舶不足の解 消そして広義には外需の促進増加につながる。

5-6 エネルギーの産業別整理と協調

工業化が進むにつれ，わが国の産業別エネルギーの 種類も多種多様にわたつてきている。その上ナフサに 関する電力と石油化学の原油論争, さらに鉄鋼のナフ サ使用への動きなど, 最近公害問題にからむ低イオウ 然料をめぐつて産業間の競合が目立つてきた。エネル ギーの堅調が哚刻になるにつれ，この傾向も強くなる と予想され，このままでは混乱をまねき価格高騰の原 因にもなりかねない。したがつてある程度産業別に燃 料種別の整理をする必要がないだろうか。

同時に原子力・L NGなど多目的利用の可能性をも つた燃料については, 産業別の密接な協調体制をとる ベきであろう。

研究体制の進め方もこの 2 点を考慮して新技術開発 事業団の委託研究も含めて分担して強力に推進すべき である。

5-7 強力なエネルギーの指導体制を

エネルギーはともすれば近視眼的になりがちであり しかも燃料別 - 産業別 - 官民別 - 会社別 - 国内外別の 複雑な構成の中で, いわゆる縦割的欠陥が出がちであ る。エネルギー事情を緩和し，不当競争を避けるため にも, 大局に立つてこれらの横のつながり，システム 化を行なら官民一体の真の指導体制が必要な時ではな かろらか。また価格体系についても長期展望に基づく 大きな流れは調制することが必要であろう。

ウラン開発など軌道に乗る前にすでにウラン節約の 原子炉がスタートしようとしており, 将来も含めた開 発環境を育成することが先決である。

\section{6. エネルギーにイニシャチーブを}

これまで発展した日本産業もエネルギーに関しては 
そのほとんどを海外に依存し，しかも各エネルギーと も主導権を外国に握られている。わが国としても自国 の発言力をもつ開発を促進すべきことは当然である が，エネルギー資源の開発には多くの年月と投資・ ウハウを要し，しかも各エネルギーとも外国資本・技 術の網が張りめぐらされ, 前途法決して容易なもので はない。この遅れを取り戻し, エネルギー全般にバー ゲニングパワーをもつためにも，エネルギーの新方 向, 新資源の開発化㧤いて, 独自の施策, 技術を生み 出し自由世界GN P 2 位, 外貨保有 3 位の誇りをもつ て，エネルギーに何かイニシャチーブを㨔む時がきた といえる。そのためには技術・投資を集中して新資源 の開発, 利用流通の面で独自の, または先発性ある方 策を見出すことが必要であろら。

以下施策の要に述べたことも考え, 進むべき方向の 示唆を例示しょう。

\section{7. 還元鉄の原料地生産}

最近の製鉄技術の大半は原料炭の節約に向けられ, これに伴い還元鉄が一つには直接製鉄・一貫製鋼につ ながる技術として，もら一つは高炉のコークス比減少 のための予備還元鉄として注目され始めた。この方法 は低品位鉱の使用も可能であり，還元剤としては天然 ガス・石油・石炭類（褐炭を含む全石炭類）が用いら れ，現在の高炉用コークスのような厳しい制約はなく また小規模でも割安な投資で可能とされる。原子力製 鉄もこの一種で「高炉 $+\mathrm{L} D$ 転炉」に対する「還元鉄 十電気炉」は将来の鉄鋼新技術といわれている。

もちろん，これからの技術でありまだ多くの問題点 はあるが，最近 SL/RN，Midland-loss，F I ORな ど急速に伸びてきて抢り, UHP電気炉の発達に伴い 「ミニミル」として注目をあびている。

鉄鉱と化石燃料の共存地で還元鉄の生産を行なえば 原料は安くコストも低廉であり，一方フレートの節約 公害防止，海外経済協力にもつながる。とくに固体還 元法は褐炭や高揮発分瀝青炭の方が反応性もよく, こ れら非粘結炭は鉄鉱石と共存して世界各所傄存し, オーストラリア, 東南アジア, カナダ, 南アメリカ, 南アなどがあげられる。将来 1 億 $\mathrm{t}$ を超すといわれる 世界的に乏しい原料炭の節約にもつながる鉄鋼新資源 の活用となりわが国のエネルギー事情の緩和にも役 立つ。国内でも安い非粘粘炭であれば可能であり，原 子力多目的利用として直接製鉄用の還元ガス発生源と しても組合せることが可能である。（後述のガルフグ ループの原子力による低品位炭のガス化参照）

\section{8. 石炭のガス化と液化}

アメリカは1960年エネルギー革命の当初に OCR (石 炭研究局）を設立，石炭の将来技術特に液化・ガス化 に取り組んできた。OCR の特色は諮問委員会でテー マを選び, 民間会社, 大学と研究契約を結んで委託し ていることである。1967 年の予算は研究費のみで 166 億円5ち石炭液化76億円, ガス化24億となうている。 最近アメリカの将来エネルギーに対する不安からこれ らがクローズアップされ，これ以上の輸入然料の増大 を阻止するため経済的石炭液化・ガス化の緊急性が強 調され, コチヤラン石炭局長はその促進のため今後 10 年に $5 \sim 7.5$ 億ドルが必要であるといつている。

石炭液化にはC S F 法 (Consolidation Coal Co.) H-Coal 法 (Hydrocarbon Research Inc.), C O E D 法 (FMC Corp.), Seacoke 法 (Atlanttic Refining Co.) があり，いずれも水蒸気改質による水素を用い る水素添加方式であり, 従来法と異なり分離し易い部 分のみ液化する法で, 若い環数の少い高揮発分炭が適 する。いずれもパイロットプラントをもち，コマーシ ヤルプラントの検討がなされている。

H-Coal 法では $1 \mathrm{t}$ の石炭 (4.5ドル) から 3.6 4 bbl のL S 重油が 2.8 ドル/bbl 程度でできると試算さ れ，CF S 法では $1 \mathrm{t}$ から $3.1 \mathrm{bbl}$ の粗生ガソリンが 4.7 ドル/bbl 程度で仕上ると試算されていた。(575万 $\mathrm{t} /$ 年 の瀝青炭で 1,800 万bbl のガソリンと 150 万 $\mathrm{t}$ の 無煙燃料を供給)

ガス化は Hygas 法( I G T, Institute of Gas Technology), $\mathrm{CO}_{2}$ Acceptor 法 (C S G, Comsolidation Coal Co.), Molton Salt 法 (M.W. kellogg Co.), Two-Stage Superpressure 法(Bituminous Coal Rese-arch Co. ) などがあり，いずれも石炭からメタンガス を変成する方法である。

Hygas 法では $1 \mathrm{t}$ の石炭から $540 \mathrm{~m}^{3}$ のメタンガス を50 60セント $/ \mathrm{tcf}\left(6.3 \sim 7.6\right.$ 円 $\left./ \mathrm{m}^{3}\right)$ で生産できると している。I G T は 1,700万 m²/日 の設備を 3.53 億ド ルの投資で，C S G 750 万 $\mathrm{m}^{3}$ /日 の設備を 1.21 億ド ルでコマーシャルプラントを考えている。

石炭の液化・ガス化はすでに実用化化近い技術であ り，アメリカと共同して東南アジア，オーストラリア など日本の近くで, L S S 重油, 軽質油としてまたはL NGを生産して日本に運ぶか, C T S に石炭を運んで, ここで液化・ガス化することも考えるべきではなかる らか。

\section{9. 海水ウランの採取と海洋エネルギーの利用}

海水中のウランは $\mathrm{t}$ 当り $3.4 \mathrm{mg}$ 前後ではあるが, その総量は 40 億 $\mathrm{t}$ にもおよび，黒潮潮流のみで年間 
222万のウランが動いているといわれる。

現在イギリスは海水ウラン採取に䀣命であり，わが 国でも最近京大原子力炉実験所グループはダム式干満 差利用方鉛鈗吸着による海水ウラン採取計画を発表し ている。（1日 2 億 $\mathrm{t}$ の海水処理をしてウラン採取年 $120 \mathrm{t})$ わが国の大型プロゼクトとして価值ある課題 ではなからか。

吸着法のキーポイントは吸着剂であり, 含水酸化チ タンや天然方鉛鉱などが考えられているが，水銀吸着 に研究されているキーレン構造による吸着のような人 エモレキュラーシーブによる吸着率の高い安価な吸着 鼡を見出すことができないだろらか。

価格的には天然ウラン換算で $\mathrm{t}$ 当り 1,000万円以下 であることが前提であるので，地形の利用などにより 投資の大部分を占める建設費の節減をはかることが先 決であろう。最近設置または計画中の海橋を利用し， 潮流そのものを吸着剤のすだれを通してウラン採取す ることも考えられないだろらか。

いずれにせよ海洋構築となるので潮汐発電・ピーク 時の揚水発電など多目的海洋開発と併用して計画され るべきであろう。

\section{0. 原子力多目的利用基地の設立}

いらまでもなく将来エネルギーの基幹はウラン節約 技術も含め原子力にあり，これと豊富な石炭類をエネ ルギー源とし，石油・天然ガスを合成化学の原料に使 用するのがエネルギーバランス上もつとも好ましい。

しかも省エネルギーの立場からは当然原子力の多目 的利用を考えるべきで, 高温ガス冷却炉を中心に原子 力製鉄はもちろん，前述の固体流体・エネルギーのガ ス化・液化，海水の淡水化などに組合せ，将来の諸利 用を包含した原子力多目的基地の設立を提唱するもの である。

\section{1. 熱効率向上技術の推䢨}

エネルギー事情がタイトなだけに，省エネルギ一化 のため熱效率向上技術の推進をはかるべきである。

現在火力発電の平均熱効率沬 $40 \%$ 以下であり, 原子 力発電も30\%以下といわれている。そのた注前述 の原子力の多目的利用のような応用酒はもちろん, 発 電機本体の高効率化，与なわち燃料電池・ MHD発電 の実用化を促進すべきであるら。とくにMHD発電は 工業技術院を中心に独自の技術開発が行なわれてお り, 今後の発展が期待される。

\section{2. 総合エネルギ一基地の建設}

最近日本近海大陸棚の開発が叫ばれ, 外資系も参加 各所で探鈗の気運が高まりつつある。
日本列島贸皮曲帯に沿つて北海道から八重山諸島に到 る間，含油層と見られる新第三紀層の堆積があり，世 界でも残り少ない処女地である。

一方ぼら大な石油需要に対処するため, 備蓄が問題 となり，CTSの設置が強調されている。すでに鹿児 島喜入基地（最終 600 万 t ）の建設をはじめ，徳島県 桶湾など各地で計画が進められている。

これらを統合してエネルギ一総合基地をつくつては どらであろらか。北海道, 九州, 日本海, 太平洋の島 璜または沿岸過踈地が候補地としてあげられ，九州は 南方・中東継地として，北海道はサハリン・ヤクート の中継地として考えられる。同時に日本大陸棚の石油 天然ガスの探鉙開発基地として利用し, 生産, 輸送, 精製の総合基地として，パイプで本州ネットに連絡す る。これにより二重投資を避け，公害防止をもはかる ことができよう。

\section{3、エネルギーの総合利用体制}

前述のようにエネルギーの共存共栄, 融通性をはか るためにも, 天然ガス一都市ガス一合成ガスのパイプ ラインの互換性, 石油との共用も可能な輸送ラインネ ットをこれからの然料輸送計画に盛み込むべきであろ ら。同時に超高圧送電も含め全国送電ネットの早期完 成が必要である。

\section{4. 自らの資源は自らの手で}

スタンダード $(\mathrm{N} . \mathrm{J}$.) 会長ジェミソン氏は「今こ そ世界各国は国際的加長期的視野に立つて総合エネ ルギー対策を明確化する必要がある」といつている。

なんとしても自国のエネルギーは自らの手で解決せ ねばならない。国際協調の中で日本の将来の繁栄を続 けてゆくためにも, 独自の施策・技術を樹立し, エネ ルギーに対するバーゲニングパワーを持ちたいと願ら のは私一人ではあるまい。原料の長契購売方式のみに 頼ることは日本の資源開発技術を殺すことであり，自 らの技術を開発できる施策を切に望むものである。

\section{文献}

1) Der Energieauben handel westeuropäischer Lü der:W. Müller-Nichaelis, BP Benzin uxd Petroleum AG, Hamburg 1969

2) Esso, Hamburg 1971

2）チエス・マンハッタン銀行資料, P.P.S., 1970年 9 月

4）「西欧のエネルギー源」欧州石炭協会，1971年 3 月

5 ) コンチネンタルオイル社長マクリーン氏講演, 1968年 9 月，「西欧のエネルギー源より」 
6) P.P.S. 日本語版 1970年 9 月号

7 ) チェス・マンハッタン銀行資料

3) 矢崎治雄, ノ一ス・ スロープの石油探鉣・開発, 燃協誌, 50, 528

9) W. Bellano, President Occidental Petroleum Corp. : World estimates of coking coal demand, $1970 \sim 1980$

10) Draft Report on the Problems \& Prospects in the Coking Industry in the OECD countries, OECD Paris Mar. 1971

11）武中俊三，強なる国家の役割（ウラン），エコ） ミスト 昭 45.10 .6

12) P.P.S., Jan. 1970

13) アメリカ原子力委員会委員長シーボルグ博士,「西 欧のエネルギー源」より

\title{
The Problems of Our Indigenous Energy must be Solved by Ourselves
}

\author{
by Shungo Shimozawa
}

(Japan Oversea Coking Coal Development Co., Ltd.)

SYNOPSIS:- On the one hand, now the buyer's market in going to finish and the era of potential over-supply and low prices may gradually pass away.

On the other hand, the growth in energy demand is accelerating through the world.

In the background like this, Japan must seek for huge energy that will reach one billion $\mathrm{k} l$ of oil equivalent in 1985 .

Because of energy's security, now decisive policies need.

a) Exact recognition of the energy resources.

b) Co-ordination between energy and energy, and of countries each other.

c) Look over again of energy sources (speciaily coals ond ocean energy)

d) The mutual relation energies and a elasticity to energy.

e) Downstream in the producing countries of energy resources.

f) Arrangements of used energy and Co-ordinations of new energy's utilization between energies.

g) A institution of a strong organization for our energy

Under these strong policies, we would expect developments of new projects to take the initiative.

a) Manufacture of reduced iron at contries with rèsources.

b) Hydrogeration of coal to produce synthetic petrol and gasification of offset natural gas.

c) Collecting uranium from sea water and utilization of ocean energy,

d) Establishnent of combinates for uses of numerous purposes of atomic energy (Atomic iron, Gastification and Electric generation, etc.)

e) Promotion of technology of thermal efficiency-up(M.H.D. generator, fuel battery)

f) Establishment of overall energy stations for stockpile and development.

g) Mutual utilization of energy installations (pipe lines etc.) 